\title{
2017-18 Congressional Fellowship Program Roster
}

$\mathrm{F}$ ounded in 1953, the APSA Congressional Fellows Program is the nation's oldest and most prestigious congressional fellowship. The program remains devoted to its original objective of expanding knowledge and awareness of Congress. For nine months, select political scientists, journalists, doctors, federal executives, and international scholars gain "hands on" understanding of the legislative process by serving on congressional staffs. Through this opportunity, the association enhances public understanding of policymaking and improves the quality of scholarship, teaching, and reporting on American national politics.

POLITICAL SCIENTIST FELLOWS

Emily Baer, PhD, University of Minnesota

Christopher Baylor, PhD, University of California, Los Angeles

Eric van der Vort, PhD candidate, Syracuse University

Ryan Williamson, PhD, University of Georgia

Carolina Ferrerosa Young, PhD candidate, Columbia University

\section{JOURNALIST FELLOW \\ Bridget Balch, \\ Houston Chronicle}

\author{
FEDERAL EXECUTIVE FELLOWS \\ Deborah Hobson, \\ Intelligence Community \\ Morgan Large, \\ Intelligence Community \\ Summer Lockerbie, PhD, \\ Physical Scientist, National Nuclear \\ Security Administration \\ Mathew Stanley, \\ Intelligence Community
}

\section{HEALTH \& AGING POLICY FELLOWS} Residential

Carmen Castro, DrPH, Program Manager, Harris County LongTerm Care Ombudsman Program, University of Texas Health Science Center, School of Nursing

Lori Frank, PhD, Senior Advisor, Patient-Centered Outcomes Research, Patient-Centered Outcomes Research Institute (PCORI)
Lynn Hallarman, MD, Director of Palliative Care Services, Stony Brook University Hospital

Terri D. Lewinson, PhD, MSW, Associate Professor, School of Social Work, Andrew Young School of Policy Studies, Georgia State University

\section{Non-Residential}

M. Batchelor-Murphy, BSN, MSN, PhD, Gerontological Registered Nurse and Family Nurse Practitioner; Assistant Professor, Duke University School of Nursing

Robert Burke, MD, MS, Academic Hospitalist, Veterans Affairs Eastern Colorado Health Care System

Anne Fabiny, MD,

Associate Chief of Staff for Geriatrics, Palliative and Extended Care, San Francisco Veterans Affairs Medical Center

Adam Golden, MD, MBA,

Associate Chief of Staff, Geriatrics and Extended Care, Orlando Veterans Affairs Medical Center; Professor, Internal Medicine, University of Central Florida College of Medicine

Aaron Leppin, MD, MSc,

Research Associate and Assistant Professor, Mayo Clinic

Ann M. O'Hare, MD,

Veterans Affairs Staff Physician, Veterans Affairs Puget Sound Health Care System; Professor of Medicine, University of Washington, Seattle

Tiffany Riser, RN, MSN, MPH, ANP-C, Registered Nurse Practitioner and Case Manager, Veterans Affairs Palo Alto Health Care System

Fei Sun, PhD, MSW, Associate Professor, School of Social Work, Michigan State University

\section{ROBERT WOOD JOHNSON}

FOUNDATION HEALTH POLICY

\section{FELLOWS}

Carrie Colla, PhD, Health Economist and Associate Professor, Dartmouth Institute for Health Policy and Clinical Practice, Geisel School of Medicine

Robin Fleming, PhD, MN, RN, NCSN, Interdisciplinary Researcher, Author, Program Developer, and Policy Expert in the fields of health and education
Caprice Knapp, PhD,

Director, Pan Institutional Network for Global Health, Pennsylvania State University; Research Associate Professor, Health Policy and Administration (HPA) Program, Pennsylvania State University; Visiting Professor, College of Public Health, University of the Philippines, Manila

Allison Myers, PhD, MPH,

Co-founder and Executive Director, Counter Tools, Inc., a nonprofit dedicated to advancing place-based public health

Karin Rhodes, MD, MS,

Emergency Physician, Health Services Researcher, Vice President for Care Management Design and Evaluation, Office of Population Health, Northwell Health; Professor of Emergency Medicine and Psychiatry, Zucker School of Medicine, Hofstra University/Northwell Health

Reginald Tucker-Seeley, ScD, Assistant Professor of Gerontology, Leonard Davis School of Gerontology, University of Southern California (USC); Principal Investigator, Tucker-Seeley Research Lab, USC

\section{SASAKAWA PEACE FOUNDATION USA FELLOW}

Koki Fukasaku, Associate, Matsushita Institute of Government and Management

\section{SPIRIT MOUNTAIN COMMUNITY}

\section{FUND - MARK HATFIELD FELLOW}

\section{Karlen Yallup,}

Contracts, Grants, and Budget Analyst, Confederated Tribes of Warm Springs 


\section{APSA RBSI Summer Institute}

The Ralph Bunche Summer Institute (RBSI) is an annual, intensive five-week program held at Duke University. This year, it will be held between May 27 and June 28, 2018. It is designed to introduce to the world of doctoral study in political science those undergraduate students from under-represented racial and ethnic groups or those interested in broadening participation in political science and pursuing scholarship on issues affecting under-represented groups. Participants in the RBSI are drawn from a competitive national applicant pool.

Applications are open until January 19, 2018. For more information visit us online: apsanet.org/rbsi. -

\section{APSA Minority Student Recruitment Program}

Thank you to all 46 MSRP political science departments who have enrolled for 201718 and have been actively recruiting students from underrepresented backgrounds to $\mathrm{PhD}$ programs in political science. Faculty, please submit your student's name to MSRP program so that they can be receive recruitment information from MSRP departments.

To submit names, visit us online: apsanet.org/msrp. .

\section{A Virtual Review: Gender, Race, Ethnicity, and Diversity in APSA Publications}

Just over five years ago, the Task Force on Political Science in the 21st Century, led by co-chairs Luis Fraga and Terri Givens and 2007-2008 APSA President Dianne Pinderhughes, addressed the preparedness of the discipline to respond to the changing demographics, increasing multicultural diversity, and ever-growing disparities in higher education. The task force report (2011) offered recommendations to the discipline on political science research, recruitment and hiring, and teaching on racial, ethnic, and gendered marginalization. To mark the anniversary of the task force report, Dianne Pinderhughes and co-author Maryann Kwakwa were invited to identify and review a sample of articles that have appeared in the association's journals in recent years that engage issues of gender, race, ethnicity, and diversity.

Read the virtual issue online: apsanet.org/apsavirtualissues.

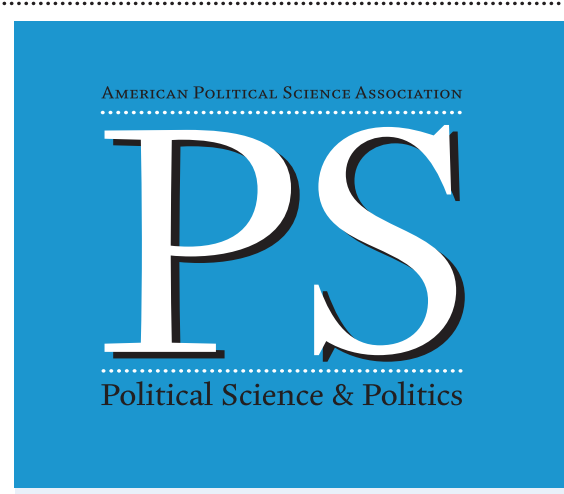

\section{In the Next}

Issue...

\section{ARTICLES}

The Chicken and Egg Question: Satisfaction with Democracy and Voter Turnout

André Blais and Filip Kostelka

Direct-Democracy Rules: The Effect of Direct Democracy on State Immigration Legislation

Andrea Silva

The Gender Balance Assessment Tool (GBAT): A Web-Based Tool for Estimating Gender Balance in Syllabi and Bibliographies

Jane Lawrence Sumner

Policing Us Sick: The Health of Latinos in an Era of Heightened Deportations and Racialized Policing Alana M.W.LeBrón, Vanessa Cruz Nichols, and Francisco I. Pedraza

Respectability, Anti-Respectability, and Intersectionally Responsible Representation

Chaya Y. Crowder and Dara Z. Strolovitch

Shifting Standards for Political Methodologists? Historical Trends in the Society for Political Methodology Sara McLaughlin Mitchell

Simulated Complexity: A New Classroom Simulation to Teach about Campaign-Finance Laws

Dick M. Carpenter II and Joshua Dunn

Why We Need to Return to the Ethics of Political Representation Suzanne Dovi and Eline Severs 